\title{
Baicalein reduces endometriosis by suppressing the viability of human endometrial stromal cells through the nuclear factor- $k B$ pathway in vitro
}

\author{
ZHIXING JIN $^{1,2^{*}}$, JIANQIN HUANG ${ }^{3 *}$ and ZHILING ZHU ${ }^{3}$ \\ ${ }^{1}$ Department of Obstetrics and Gynecology, Shanghai Medical College of Fudan University; ${ }^{2}$ Shanghai Key Laboratory \\ of Female Reproductive Endocrine Related Diseases, Fudan University; ${ }^{3}$ Department of Integrated Traditional and \\ Western Medicine, Obstetrics and Gynecology Hospital of Fudan University, Shanghai 200011, P.R. China
}

Received May 8, 2016; Accepted March 17, 2017

DOI: $10.3892 /$ etm.2017.4860

\begin{abstract}
The aim of the present study was to evaluate the effects of baicalein on human endometrial stromal cells in vitro. Ectopic endometrium samples were obtained from 6 female patients with ovarian endometriosis who underwent laparoscopic surgical procedures from July to September 2015. After culturing the cells, immunocytochemistry was performed to verify the purity and homogeneity of the endometrial stromal cells, and a Cell Counting Kit-8 assay was used to evaluate cell viability. In addition, cell cycle progression was analyzed using flow cytometry, and the effects of baicalein on the expression of B-cell lymphoma 2 (Bcl-2), Bcl-2-associated $\mathrm{X}$ protein (Bax), proliferating cell nuclear antigen (PCNA) and cyclin D1 in endometrial stromal cells were evaluated using western blot analysis. The related signaling pathways were also investigated by incubating cells with inhibitors of signaling pathways, prior to adding $40 \mu \mathrm{M}$ baicalein for $48 \mathrm{~h}$, followed by analysis of cell viability using a Cell Counting Kit- 8 assay. The results indicated that treatment with baicalein significantly induced a dose-dependent decrease $(\mathrm{P}<0.05)$ in the viability of human endometrial stromal cells, which was abolished by inhibition of the nuclear factor (NF)- $\kappa \mathrm{B}$ signaling pathway. However, baicalein treatment did not induce a time-dependent decrease in viability, as cell viabilities between the 24, 48 and $72 \mathrm{~h}$ treatment groups did not differ significantly. The number of cells in the G0/G1 phase significantly increased following treatment with baicalein $(\mathrm{P}<0.05)$, while the number of cells in the $\mathrm{S}$ and $\mathrm{G} 2 / \mathrm{M}$ phases significantly decreased $(\mathrm{P}<0.05)$.
\end{abstract}

Correspondence to: Professor Zhiling Zhu, Department of Integrated Traditional and Western Medicine, Obstetrics and Gynecology Hospital of Fudan University, 128 Shenyang Road, Shanghai 200011, P.R. China

E-mail: zhilingzhu888@126.com

${ }^{*}$ Contributed equally

Key words: baicalein, endometriosis, cell viability, nuclear factor- $\kappa \mathrm{B}$ pathway
Baicalein-treated cells also exhibited significantly reduced expression of Bcl-2, PCNA and cyclin D1 compared with control cells $(\mathrm{P}<0.05)$. These results suggested that baicalein may suppress the viability of human endometrial stromal cells through the $\mathrm{NF}-\kappa \mathrm{B}$ signaling pathway in vitro, and may induce apoptosis and promote cell cycle arrest at the G0/G1 phase. Thus, baicalein may provide a novel treatment option for endometriosis.

\section{Introduction}

Endometriosis is a benign, hormone-dependent disease that affects at least $10-15 \%$ of women of reproductive age (1). Endometriosis is characterized by immunological and inflammatory reactions in the pelvis, as well as the presence of a functional endometrium outside of the uterine cavity, which leads to pelvic pain and infertility. Although numerous studies have focused on endometriosis, its underlying pathogenic mechanisms remain unknown. An established hypothesis for the pathogenesis of endometriosis is retrograde menstruation, which was proposed by Sampson in 1927 (2). Surgery and medicine are current treatment options for endometriosis. Although endometriotic lesions may be removed during surgery, complete elimination of the lesions is rarely achieved, and post-operative relapse typically occurs (3). The hypo-estrogenic status caused by pseudopregnancy therapy, such as oral contraceptives, and pseudomenopause therapy, such as gonadotropin-releasing hormone-analogs, are often effective in the short-term treatment of endometriosis; however, associated side effects limit the use of these therapies in the long-term (4). Therefore, safe and effective treatments for endometriosis in the long-term are required.

Although endometriosis is a benign disease, previous results have suggested that it represents the initial stages of neoplastic processes (5). In particular, atypical endometriosis may represent a transitional stage between benign disease and cancer. Common features shared by endometriosis and cancer include the ability to evade apoptosis, adult stem cell-like dysregulation, neovascularization, a progressive course, implantation at distal sites, the creation of a microenvironment that enables 
cells to become anchorage-independent, and mobilization of the immune system (6).

Baicalein (5,6,7-trihydroxyflavone) is a component derived from the root of Scutellaria baicalensis Georgi, a plant traditionally used in Chinese herbal medicine (7). This compound possesses antioxidant activity (8-10) and has been documented to have numerous pharmacological properties, including anti-inflammatory, anti-bacterial, anti-viral, anti-allergy, anti-oxidation and cytoprotective effects (11). The anti-tumor effects of baicalein have been the focus of recent studies. For instance, cellular and animal experiments have demonstrated that baicalein exerts strong anti-tumor effects by acting on multiple signaling pathways, including those involved in cell proliferation, apoptosis, caspase activation, tumor suppression, death receptor activation, mitochondrial function and protein kinase activation (12-15). Previous results have also verified that baicalein serves a key role in the inhibition of tumor cell proliferation, particularly in ovarian cancer (16). However, to the best of our knowledge, no studies have been conducted to investigate the effect of baicalein on endometriosis.

As baicalein exhibits a wide range of anti-tumor effects, is easily obtained, produces little toxicity, causes few side effects, and has demonstrated potential in treating cancer (17), it may be a promising therapeutic agent in the treatment of endometriosis. In the current study, the effect of baicalein on human endometrial stromal cells was evaluated in vitro.

\section{Materials and methods}

Patients and sample collection. The procedures for the collection of tissue samples were approved by the Ethics Committee of the Obstetrics and Gynecology Hospital of Fudan University (Shanghai, China). All patients signed an informed consent form in compliance with the code of ethics of the World Medical Association (The Declaration of Helsinki). All ectopic endometrium samples were collected from 6 female patients with ovarian endometriosis who underwent laparoscopic surgical procedures at the Obstetrics and Gynecology Hospital of Fudan University from July to September 2015. The patients were 25-42 years old, had regular menstrual cycles. Patients who had received hormonal therapy or antibiotics for at least three months prior to surgery were excluded. After collection, the tissue samples were immediately used for the isolation and culture of human endometrial stromal cells.

Isolation and culture of human endometrial stromal cells. Endometrial stromal cells were separated from the isolated endometrial tissues as described previously (18). Briefly, the tissue was finely minced and the cells were dispersed by incubation in Dulbecco's modified Eagle's medium DMEM/F-12 (Gibco; Thermo Fisher Scientific, Inc., Waltham, MA, USA) containing $1 \mathrm{x}$ antibiotics (penicillin-streptomycin solution) and $2 \mathrm{mg} / \mathrm{ml}$ collagenase II for $60 \mathrm{~min}$ at $37^{\circ} \mathrm{C}$ with agitation. The dispersed endometrial cells were separated by filtration through a $100 \mu \mathrm{m}$ filter followed by a $300 \mu \mathrm{m}$ filter. The endometrial glandular epithelium was retained by the sieve, while the dispersed stromal cells passed through the sieve into the filtrate. The stromal cells were pelleted by centrifugation at $200 \mathrm{xg}$ for $9 \mathrm{~min}$ at room temperature and suspended in DMEM/F-12 containing antibiotics ( $1 \%$ penicillin-streptomycin solution) and fetal bovine serum (FBS; 10\%, v/v; Sigma-Aldrich; Merck KGaA, Darmstadt, Germany). The cells were divided into two culture bottles after each extraction, then cells were cultured at $37^{\circ} \mathrm{C}$ in a humidified atmosphere containing $5 \% \mathrm{CO}_{2}$ and the medium was replaced with fresh medium every $48 \mathrm{~h}$. The cells were passaged when they reached $80 \%$ confluence and totally cells were passaged twice.

Immunocytochemistry. Following $72 \mathrm{~h}$ of subculture, cells were fixed with $4 \%$ paraformaldehyde for $30 \mathrm{~min}$ at room temperature. After blocking with rabbit serum (1:200; Beyotime Institute of Biotechnology, Haimen, China), the cells were incubated with rabbit anti-human vimentin (ab92547; 1:200; Abcam, Cambridge, UK) or rabbit anti-human cytokeratin 7 (CK7) antibodies (ab68459; 1:200; Abcam, Cambridge, UK) overnight at $4^{\circ} \mathrm{C}$. After three 15 min washes in PBS (pH 7.4), the cells were incubated with a mouse anti-rabbit antibody at room temperature (sc-2357; 1:50; Santa Cruz Biotechnology, Inc., Dallas, TX, USA) for $60 \mathrm{~min}$. The slides were subsequently washed in PBS and incubated with 0.01\% 3,3-diaminobenzidine tetrahydrochloride (Beyotime Institute of Biotechnology) for 2 min. The cells were then stained with chromogen substrates (Beyotime Institute of Biotechnology) for $3 \mathrm{~min}$ and counterstained with hematoxylin. Analysis was carried out under a light microscope at x400 magnification and an estimation based on microscopic observations. When $>98 \%$ of cells were positive for vimentin staining and $<2 \%$ of cells were negative for CK7 staining, it was considered that a homogeneous population of endometrial stromal cells had been isolated.

Cell viability. Cell viability was estimated using a Cell Counting Kit-8 (CCK-8; Dojindo Molecular Technologies, Inc., Kumamoto, Japan). Cells were seeded into 96-well plates at a density of 10,000 cells/well in DMEM/F-12 containing $10 \% \mathrm{FBS}$ at $37^{\circ} \mathrm{C}$. After $24 \mathrm{~h}$ of culture, the medium was replaced with DMEM/F-12 without FBS and cultured at $37^{\circ} \mathrm{C}$ for $12 \mathrm{~h}$. Baicalein was added to DMEM/F-12 containing $10 \%$ FBS to obtain concentrations of $0,5,10,20,40,80,160 \mu \mathrm{M}$ and each concentration was added to separate wells (3 wells for each concentration). At 24, 48 or $72 \mathrm{~h}$ after the addition of baicalein, the media was removed and CCK- 8 reagent was added to each well, and the plates were incubated at $37^{\circ} \mathrm{C}$ for $90 \mathrm{~min}$. Absorbance at $450 \mathrm{~nm}$ was then measured on a microplate reader (Bio-Rad Laboratories, Inc., Hercules, CA, USA). A culture solution containing CCK- 8 reagent without cells served as a blank control (BC). Cell viability rates were expressed as the ratio of the absorbance values from the experimental group to those of the negative control $(0 \mu \mathrm{M})$ group.

Western blot analysis. Cells were lysed in ice-cold radioimmunoprecipitation protein lysis buffer (Beyotime Institute of Biotechnology) and protein concentration was measured using a bicinchoninic assay kit (Beyotime Institute of Biotechnology). Equal amounts of total protein (40 $\mu \mathrm{g}$ per lane) were solubilized in sample buffer by boiling for $5 \mathrm{~min}$, then subjected to electrophoresis on $12 \%$ SDS-PAGE and transferred onto a nitrocellulose membrane (Bio-Rad Laboratories, Inc.). The membranes were incubated with a blocking buffer [1X Tris-buffered-saline (TBS) containing 5\% non-fat, dried milk and $0.1 \%$ Tween-20] for $1 \mathrm{~h}$ at room temperature. Membranes 
were then incubated with 1:1,000 dilutions of rabbit anti-human B-cell lymphoma 2 (Bcl-2), Bcl-2-associated X protein (Bax), proliferating cell nuclear antigen (PCNA), cyclin D1, $\beta$-actin and $\beta$-tubulin (cat. no. 4223, 14796, 2586, 2978, 4970 and 2128, respectively, all from Cell Signaling Technology, Inc., Danvers, MA, USA) overnight at $4^{\circ} \mathrm{C}$. The next day, the membranes were washed three times in TBS containing $0.1 \%$ Tween-20, then incubated for $60 \mathrm{~min}$ with a horseradish peroxidase-conjugated secondary antibody at room temperature (cat. no. 14708; 1:1,000; Cell Signaling Technology, Inc.). The protein bands were visualized using an enhanced chemiluminescence kit (Beijing Transgen Biotech Co., Ltd., Beijing, China). The densities of the bands were quantified using Quantity One Analysis software v4.62 (Bio-Rad Laboratories, Inc.) and normalized against the intensities of $\beta$-actin and $\beta$-tubulin.

Cell cycle analysis by flow cytometry. Approximately 10,000 cells were treated with baicalein $(0$ or $40 \mu \mathrm{M})$ for $48 \mathrm{~h}$ at $37^{\circ} \mathrm{C}$. The cells were then collected, fixed with cold $70 \%$ ethanol and stored at $-20^{\circ} \mathrm{C}$. The cells were washed, resuspended in cold PBS and incubated with $1 \mathrm{mg} / \mathrm{ml}$ propidium iodide (Sigma-Aldrich; Merck $\mathrm{KGaA}$ ) at $37^{\circ} \mathrm{C}$ for $30 \mathrm{~min}$. DNA content was measured by flow cytometry (BD Biosciences, Franklin Lakes, NJ, USA). The percentages of cells in different phases of the cell cycle were evaluated using CellQuest acquisition software version 5.1 (BD Biosciences).

Treatment with signal inhibitors. Approximately 10,000 endometrial stromal cells were incubated with or without WP1066 [signal transducer and activator of transcription 3 (STAT3) inhibitor; $10 \mu \mathrm{M}$ ], N'-(4-Oxo-4H-chromen-3-yl) methylene) nicotinohydrazide (STAT5 inhibitor; $10 \mu \mathrm{M}$ ), LY294002 (Akt signal pathway inhibitor; $10 \mu \mathrm{M}$ ), SP600125 [c-Jun N-terminal kinase (JNK) inhibitor; $10 \mu \mathrm{M}$ ], SB203580 [p38/mitogen-activated protein kinase (MAPK) inhibitor; $10 \mu \mathrm{M}$ ], U0126 [extracellular signal-regulated kinases 1/2 (ERK1/2) inhibitor; $10 \mu \mathrm{M}$ ], BAY11-7080 [nuclear factor (NF)- $\mathrm{\kappa B}$ inhibitor; $10 \mu \mathrm{M}$ ] (all inhibitors were from Santa Cruz Biotechnology, Inc.) for $6 \mathrm{~h}$ at $37^{\circ} \mathrm{C}$, then treated with or without baicalein ( $40 \mu \mathrm{M}$; Sigma-Aldrich; Merck KGaA) for $48 \mathrm{~h}$ at $37^{\circ} \mathrm{C}$. Cell viability was evaluated using a CCK-8 assay, as described above.

Statistical analysis. All statistical analyses were performed using SPSS 16.0 software (SPSS, Inc., Chicago, IL, USA). Statistical comparisons were performed using a Kruskal-Wallis test for three or more groups and the Wilcoxon signed-rank test for two groups. Data are presented as the median \pm interquartile range of three independent experiments. $\mathrm{P}<0.05$ was considered to indicate a statistically significant difference.

\section{Results}

Verification of endometrial stromal cell purity and homogeneity. The purity and homogeneity of the stromal cell preparation were verified by immunocytochemistry using an antibody against vimentin, as a specific marker of stromal cells, and an antibody against CK7, as a specific marker of epithelial cells (6). After 3-4 cell passages, based on an

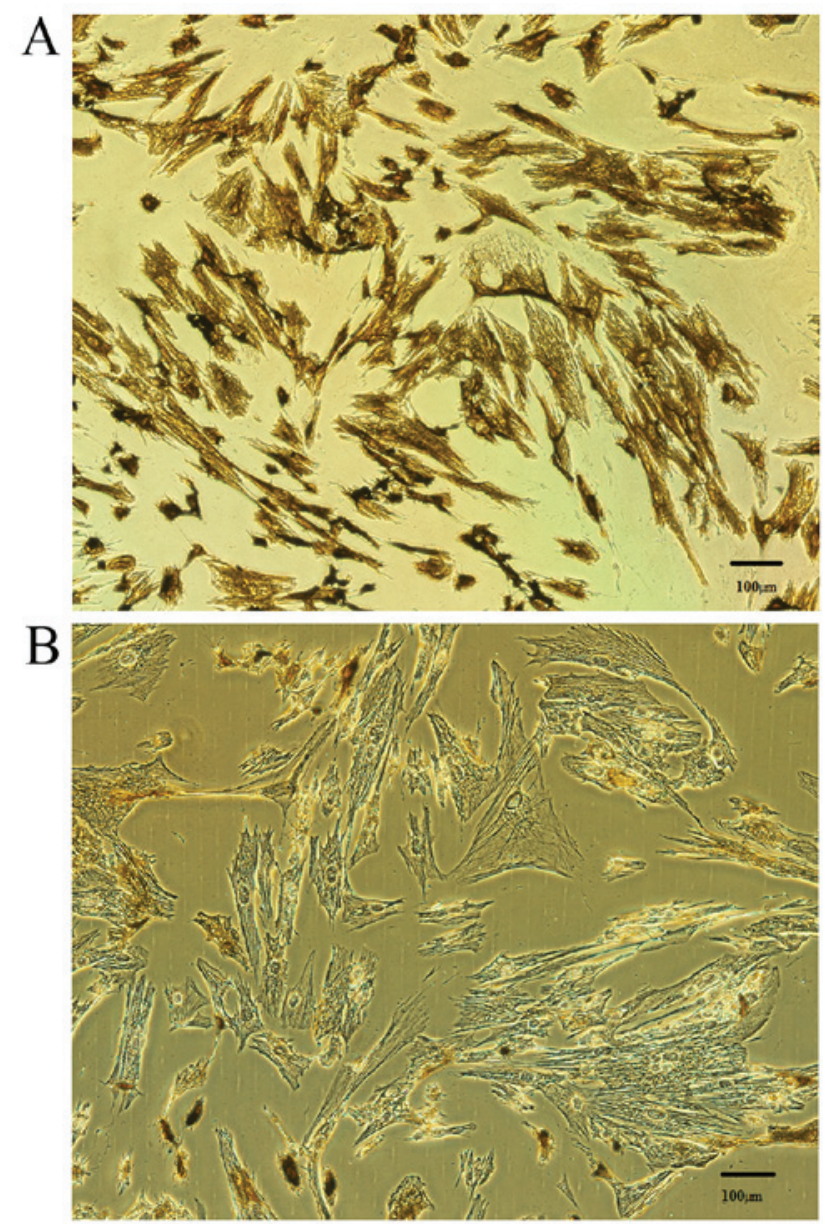

Figure 1. Verification of endometrial stromal cell purity and homogeneity. Immunocytochemistry was used to assess the levels of (A) vimentin (brown staining) and (B) cytokeratin 7 (no brown staining) expression in cells isolated from 6 female patients presenting with ovarian endometriosis. Magnification, $\mathrm{x} 400$.

estimation of microscopic observations, the vimentin staining was positive ( $>98 \%$ of cells; Fig. 1A) and the CK7 staining was negative ( $<2 \%$ of cells; Fig. 1B), indicating that a homogeneous population of endometrial stromal cells had been isolated.

Effect of baicalein on endometrial stromal cell viability. The effect of baicalein on the growth of human endometrial stromal cells in vitro was observed by light microscopy (Fig. 2A-C) and measured using a CCK-8 assay. As depicted in Fig. 2D, increasing concentrations of baicalein $(0,5,10,20,40,80$ and $160 \mu \mathrm{M}$ ) were administered for 24,48 and $72 \mathrm{~h}$, and the effect on cell viability was evaluated. As depicted in Table I, after 24, 48 and $72 \mathrm{~h}$, baicalein induced a dose-dependent decrease $(\mathrm{P}<0.05)$ in the viability of human ectopic endometrial cells. Compared with $0 \mu \mathrm{M}$ group, the viability of cells was decreased significantly in $5 \mu \mathrm{M}$ group, indicating that the minimum effective concentration of baicalein was $5 \mu \mathrm{M}$ and the half maximal inhibitory concentration was $80 \mu \mathrm{M}$. The growth rates of endometrial stromal cells at 24, 48 and $72 \mathrm{~h}$ did not differ significantly. These results suggest that baicalein may reduce the viability of human endometrial stromal cells. 
Table I. Effect of baicalein on endometrial stromal cell viability.

Cell viability (relative to control)

\begin{tabular}{|c|c|c|c|c|c|c|}
\hline \multirow[b]{2}{*}{ Baicalein $(\mu \mathrm{M})$} & \multicolumn{2}{|c|}{$24 \mathrm{~h}$} & \multicolumn{2}{|c|}{$48 \mathrm{~h}$} & \multicolumn{2}{|c|}{$72 \mathrm{~h}$} \\
\hline & Median & $\mathrm{P}_{25}-\mathrm{P}_{75}$ & Median & $\mathrm{P}_{25}-\mathrm{P}_{75}$ & Median & $\mathrm{P}_{25}-\mathrm{P}_{75}$ \\
\hline 0 & 1.000 & $1.000-1.000$ & 1.000 & $1.000-1.000$ & 1.000 & $1.000-1.000$ \\
\hline 5 & $0.939^{\mathrm{a}}$ & $0.831-0.985$ & $0.978^{\mathrm{a}}$ & $0.922-0.991$ & $0.937^{\mathrm{a}}$ & $0.902-0.987$ \\
\hline 10 & $0.897^{\mathrm{a}}$ & $0.801-0.957$ & $0.856^{\mathrm{a}}$ & $0.728-0.933$ & $0.904^{\mathrm{a}}$ & $0.763-0.928$ \\
\hline 20 & $0.814^{\mathrm{a}}$ & $0.686-0.913$ & $0.739^{\mathrm{a}}$ & $0.618-0.843$ & $0.841^{\mathrm{a}}$ & $0.571-0.914$ \\
\hline 40 & $0.730^{\mathrm{a}}$ & $0.632-0.905$ & $0.654^{\mathrm{a}}$ & $0.575-0.764$ & $0.776^{\mathrm{a}}$ & $0.538-0.844$ \\
\hline 80 & $0.603^{\mathrm{a}}$ & $0.511-0.874$ & $0.543^{\mathrm{a}}$ & $0.417-0.740$ & $0.590^{\mathrm{a}}$ & $0.431-0.798$ \\
\hline 160 & $0.541^{\mathrm{a}}$ & $0.424-0.692$ & $0.402^{\mathrm{a}}$ & $0.295-0.597$ & $0.454^{\mathrm{a}}$ & $0.284-0.511$ \\
\hline
\end{tabular}

Statistical comparisons were made using the Kruskal-Wallis test. ${ }^{a} \mathrm{P}<0.05$ vs. control group $\left(0 \mu \mathrm{M}\right.$ baicalein). $\mathrm{P}_{25}, 25$ th percentile; $\mathrm{P}_{75}, 75$ th percentile.

A

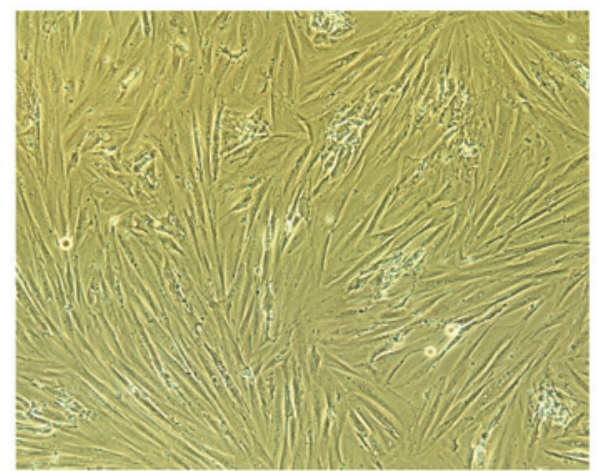

C

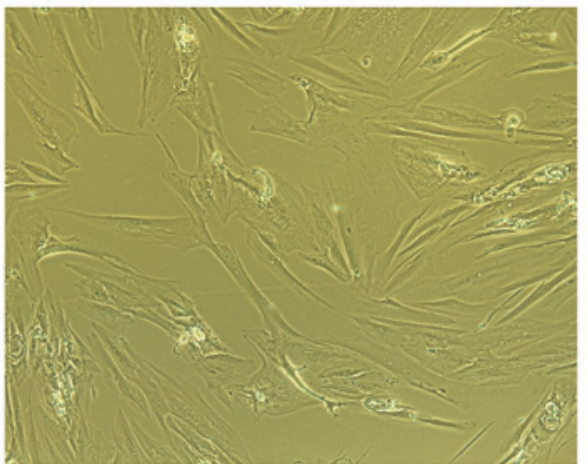

B

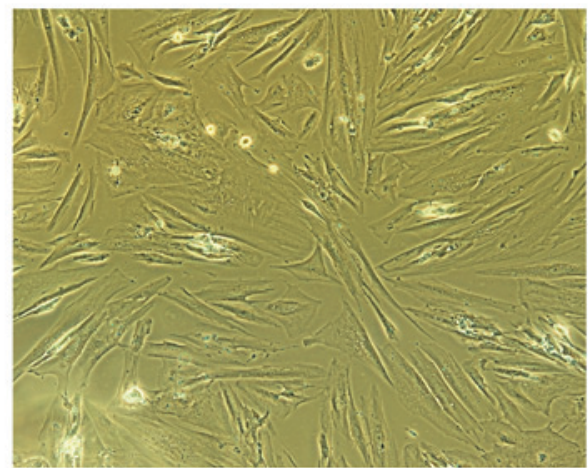

D

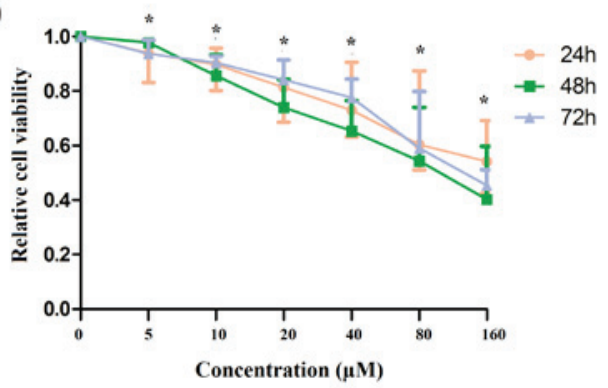

Figure 2. Effect of baicalein on endometrial stromal cell viability. Following treatment with (A) 0 , (B) 10 or (C) $40 \mu \mathrm{M}$ baicalein, the morphology of endometrial stromal cells was evaluated under a light microscope. Magnification, x400. (D) Cell viability was evaluated following treatment with the indicated concentrations of baicalein for 24,48 and $72 \mathrm{~h}$. Cell viability was expressed relative to the control $(0 \mu \mathrm{M})$. Statistical comparisons were made using the Kruskal-Wallis test and results are presented as the median and interquartile range (25-75th percentile). ${ }^{*} \mathrm{P}<0.05$ vs. control.

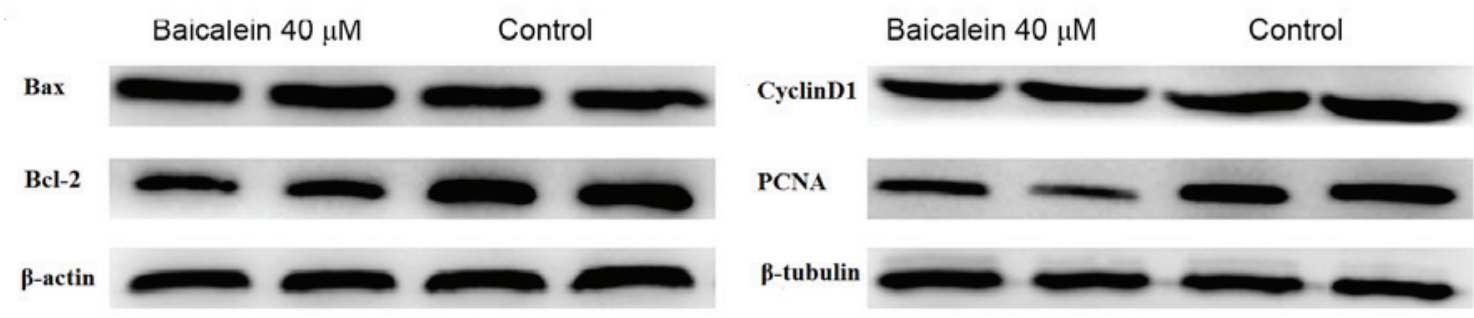

Figure 3. Effect of baicalein on the expression of Bcl-2, Bax, PCNA and cyclin D1 in endometrial stromal cells. Cells were treated with $0 \mu \mathrm{M}$ (control) or $40 \mu \mathrm{M}$ baicalein for $48 \mathrm{~h}$, and western blot analysis was used to evaluate the expression of Bcl-2, Bax, PCNA and cyclin D1. Bcl-2, B-cell lymphoma 2; Bax, Bcl-2-associated X protein; PCNA, proliferating cell nuclear antigen. 
Table II. Effect of baicalein on endometrial stromal cell cycle progression measured by flow cytometry analysis.

\begin{tabular}{|c|c|c|c|c|}
\hline \multirow[b]{2}{*}{ Cell cycle stage } & \multicolumn{2}{|c|}{ Baicalein $0 \mu \mathrm{M}(\%$ cells $)$} & \multicolumn{2}{|c|}{ Baicalein $40 \mu \mathrm{M}$ (\% cells $)$} \\
\hline & Median & $\mathrm{P}_{25}-\mathrm{P}_{75}$ & Median & $\mathrm{P}_{25}-\mathrm{P}_{75}$ \\
\hline G1 & 61.52 & $60.23-63.62$ & $82.54^{\mathrm{a}}$ & $80.45-83.61$ \\
\hline S & 21.82 & $20.16-22.53$ & $13.69^{\mathrm{a}}$ & $12.28-14.57$ \\
\hline G2/M & 16.17 & $15.21-17.36$ & $4.12^{\mathrm{a}}$ & $3.98-5.21$ \\
\hline
\end{tabular}

Statistical comparisons were made using the Wilcoxon test. ${ }^{a} \mathrm{P}<0.05$ vs. control group $(0 \mu \mathrm{M}$ baicalein $) . \mathrm{P}_{25}, 25$ th percentile; $\mathrm{P}_{75}, 75$ th percentile.

Table III. Effect of baicalein on the expression of Bcl-2, Bax, PCNA and cyclin D1.

Relative expression

\begin{tabular}{lcccc}
\cline { 2 - 3 } Protein & \multicolumn{2}{c}{ Baicalein $0 \mu \mathrm{M}$} & \multicolumn{2}{c}{ Baicalein $40 \mu \mathrm{M}$} \\
\cline { 2 - 3 } \cline { 5 - 5 } & Median & $\mathrm{P}_{25}-\mathrm{P}_{75}$ & & Median \\
\hline Bcl-2 & 1.000 & $1.000-1.000$ & $0.661^{\mathrm{a}}$ & $0.629-0.762$ \\
Bax & 1.000 & $1.000-1.000$ & 1.061 & $0.993-1.141$ \\
PCNA & 1.000 & $1.000-1.000$ & $0.683^{\mathrm{a}}$ & $0.652-0.713$ \\
Cyclin D1 & 1.000 & $1.000-1.000$ & $0.698^{\mathrm{a}}$ & $0.659-0.701$ \\
\hline
\end{tabular}

Statistical comparisons were made using the Wilcoxon test. ${ }^{a} \mathrm{P}<0.05$ vs. control group ( $0 \mu \mathrm{M}$ baicalein). $\mathrm{P}_{25}, 25$ th percentile; $\mathrm{P}_{75}, 75$ th percentile; Bcl-2, B-cell lymphoma 2; Bax, Bcl-2-associated X protein; PCNA, proliferating cell nuclear antigen.

Effect of baicalein on endometrial stromal cell cycle progression. To determine the effects of baicalein on cell cycle progression, flow cytometry analysis was performed. As depicted in Table II, the number of cells in the G1 phase significantly increased following treatment with baicalein for $48 \mathrm{~h}$, relative to the control $(\mathrm{P}<0.05)$, while the number of cells in the $\mathrm{S}$ and $\mathrm{G} 2 / \mathrm{M}$ phases significantly decreased following baicalein treatment $(\mathrm{P}<0.05)$.

Effect of baicalein on the protein expression level of Bax, Bcl-2, PCNA and Cyclin D1. The effect of baicalein on the expression of apoptotic proteins was evaluated. As depicted in Fig. 3 and Table III, the level of Bax protein did not change significantly, while the level of $\mathrm{Bcl}-2$ protein significantly decreased following baicalein treatment, relative to the control $(\mathrm{P}<0.05)$. The expression of PCNA was also used to evaluate cell proliferation following treatment with baicalein. It was observed that treatment with baicalein caused a significant decrease in the level of PCNA protein compared with the control $(\mathrm{P}<0.05$; Fig. 3 and Table III). In addition, levels of Cyclin D1, as a marker of the M to G1 transition of the cell cycle, were significantly reduced by baicalein treatment when compared with the control ( $\mathrm{P}<0.05$; Fig. 3 and Table III).

Effect of baicalein on endometrial stromal cell viability after inhibition of signaling pathways. To investigate the signaling pathways related to baicalein activity in endometrial stromal cells, the viability of endothelial stromal cells was evaluated following treatment with baicalein and inhibitors of different signaling pathways. As depicted in Table IV, the inhibitor of NF- $\kappa B$ signaling (BAY-11-7080) reversed the decrease in cell viability induced by baicalein. By contrast, the viabilities of cells treated with Akt, p38/MAPK, ERK1/2, STAT3, JNK or STAT5 inhibitors remained significantly reduced by baicalein treatment, relative to the control (all $\mathrm{P}<0.05$; Table IV). These results suggest that the inhibitory effects of baicalein on endometrial stromal cells may involve NF- $\mathrm{kB}$ signaling.

\section{Discussion}

Endometriosis is among the most prevalent types of benign gynecological diseases, and shares a number of characteristics with tumors (19). Current treatments for endometriosis involve surgery and the administration of hormones. However, the high recurrence rates of endometriosis and the various side effects of treatments (20) limit their clinical application. Therefore, recent studies have focused on identifying therapeutic strategies with greater efficacy. In China, traditional herbal preparations account for $30-50 \%$ of the total medicinal consumption (21). Traditional medicine is popular in all regions of the developing world, and its use is spreading in developed countries (22). In recent years, medicinal herbs have become popular for the management of symptoms associated with endometriosis $(23,24)$.

The effects of baicalein have been studied in numerous types of malignancy, including osteosarcoma, gallbladder 
Table IV. Effect of signal pathway inhibition on endometrial stromal cell viability.

Cell viability (relative to control)

\begin{tabular}{lllr} 
Treatment & Inhibited signal & Median & \multicolumn{1}{c}{$\mathrm{P}_{25^{-}} \mathrm{P}_{75}$} \\
\hline Baicalein $0 \mu \mathrm{M}$ & None & 1.000 & $1.000-1.000$ \\
Baicalein $40 \mu \mathrm{M}$ & None & $0.730^{\mathrm{a}}$ & $0.632-0.905$ \\
LY294002 + baicalein $40 \mu \mathrm{M}$ & Akt pathway & $0.694^{\mathrm{a}}$ & $0.524-0.753$ \\
SB203580 + baicalein $40 \mu \mathrm{M}$ & MAPK pathway & $0.715^{\mathrm{a}}$ & $0.685-0.812$ \\
WP1066 + baicalein $40 \mu \mathrm{M}$ & STAT3 & $0.702^{\mathrm{a}}$ & $0.498-0.792$ \\
Nicotinohydrazide + baicalein $40 \mu \mathrm{M}$ & STAT5 & $0.683^{\mathrm{a}}$ & $0.576-0.853$ \\
SP600125 + baicalein $40 \mu \mathrm{M}$ & JNK pathway & $0.741^{\mathrm{a}}$ & $0.669-0.821$ \\
U0126 + baicalein $40 \mu \mathrm{M}$ & ERK 1/2 pathway & $0.659^{\mathrm{a}}$ & $0.518-0.781$ \\
BAY11-7080 + baicalein $40 \mu \mathrm{M}$ & NF- $\kappa$ B & 1.100 & $0.978-1.135$
\end{tabular}

Statistical comparisons were made using the Kruskal-Wallis test. ${ }^{a} \mathrm{P}<0.05$ vs. control group $\left(0 \mu \mathrm{M}\right.$ baicalein). $\mathrm{P}_{25}, 25$ th percentile; $\mathrm{P}_{75}, 75$ th percentile; MAPK, mitogen-activated protein kinase; STAT, signal transducer and activator of transcription; JNK, c-Jun N-terminal kinase; ERK, extracellular signal-regulated kinase; NF- $\kappa \mathrm{B}$, nuclear factor- $\kappa \mathrm{B}$.

cancer, breast cancer and gynecologic tumors such as ovarian cancer $(23,25,26)$. Baicalein has been found to be active against a variety of cancer cell types by inhibiting cell proliferation and inducing apoptosis (27-29). However, the underlying mechanisms of action of baicalein are not well understood. Baicalein is considered to be of increasing importance due to its involvement in the suppression of many tumor-related processes, including oxidative stress, apoptosis, proliferation and metastasis $(30,31)$. Baicalein may have multiple targets that subsequently interact with a variety of proteins to modify the activity and expression of downstream target proteins, such as caspase-3, cyclin D, NF- $\mathrm{B}$ B and so on (32). Thus, baicalein may be a potential candidate for use in the treatment of cancer.

Due to the reported anti-tumor properties of baicalein and the relationship between endometriosis and cancer, the current study aimed to evaluate the therapeutic potential of baicalein in endometriosis. The effect of baicalein on endometrial stromal cell viability was assessed in vitro to provide a theoretical foundation for its use in the treatment of endometriosis, and to gain insight into the pathogenesis of this disease. It was observed that $5 \mu \mathrm{M}$ baicalein significantly reduced the viability of human endometrial stromal cells, and that this effect was more pronounced with increasing doses of baicalein. In turn, the suppressive effects of baicalein were abolished by treatment with an inhibitor of the NF- $\kappa$ B signaling pathway. Treatment with baicalein also reduced the expression of the anti-apoptosis protein $\mathrm{Bcl}-2$, indicating that baicalein may induce apoptosis in human endometrial stromal cells. Furthermore, results obtained from cell cycle analysis indicated that the number of cells in the G1 phase increased following treatment with baicalein when compared with control cells, while the number of cells in the $\mathrm{S}$ and $\mathrm{G} 2 / \mathrm{M}$ phases decreased. Therefore, baicalein effectively caused G1 phase cell cycle arrest in endometrial stromal cells. Future studies are now required to further evaluate the activity of baicalein, particularly regarding its potential effects on angiogenesis, inflammation and immunity.
In conclusion, the present study observed that baicalein significantly reduced the viability of endometrial stromal cells in vitro, potentially through mediation of the $\mathrm{NF}-\kappa \mathrm{B}$ signaling pathway. Baicalein also induced apoptosis and promoted G0/G1 phase cell cycle arrest of endometrial stromal cells.

\section{Acknowledgements}

The present study was supported by the Science and Technology Commission of Shanghai Municipality, China (grant no. 12401902200).

\section{References}

1. Bulun SE: Endometriosis. N Engl J Med 360: 268-279, 2009.

2. Sampson JA: Metastatic or embolic endometriosis, due to the menstrual dissemination of endometrial tissue into the venous circulation. Am J Pathol 3: 93-110.43, 1927.

3. Ozkan S and Arici A: Advances in treatment options of endometriosis. Gynecol Obstet Invest 67: 81-91, 2009.

4. Rocha AL, Reis FM and Petraglia F: New trends for the medical treatment of endometriosis. Expert Opin Investig Drugs 21: 905-919, 2012.

5. Krawczyk N, Banys-Paluchowski M, Schmidt D, Ulrich U and Fehm T: Endometriosis-associated Malignancy. Geburtshilfe Frauenheilkd 76: 176-181, 2016.

6. Machado-Linde F, Sánchez-Ferrer ML, Cascales P, Torroba A, Orozco R, Silva Sánchez Y, Nieto A and Fiol G: Prevalence of endometriosis in epithelial ovarian cancer. Analysis of the associated clinical features and study on molecular mechanisms involved in the possible causality. Eur J Gynaecol Oncol 36: 21-24, 2015.

7. Kim YO, Leem K, Park J, Lee P, Ahn DK, Lee BC, Park HK, Suk K, Kim SY and Kim H: Cytoprotective effect of Scutellaria baicalensis in CA1 hippocampal neurons of rats after global cerebral ischemia. J Ethnopharmaco 77: 183-188, 2001.

8. Kimura Y, Kubo M, Tani T, Arichi S, Ohminami H and Okuda H: Studies on Scutellariae radix. III. Effects on lipid metabolism in serum, liver and fat cells of rats. Chem Pharm Bull (Tokyo) 29: 2308-2312, 1981.

9. Lin CC and Shieh DE: The anti-inflammatory activity of Scutellaria rivularis extracts and its active components, baicalin, baicalein and wogonin. Am J Chin Med 24: 31-36, 1996. 
10. Li-Weber M: New therapeutic aspects of flavones: The anticancer properties of Scutellaria and its main active constituents Wogonin, Baicalein and Baicalin. Cancer Treat Rev 35: 57-68, 2009.

11. Kim DH, Cho KH, Moon SK, Kim YS, Kim DH, Choi JS and Chung HY: Cytoprotective mechanism of baicalin against endothelial cell damage by peroxynitrite. J Pharm Pharmacol 57: 1581-1590, 2005.

12. Chen ZY, Su YL, Lau CW, Law WI and Huang Y: Endotheliumdependent contraction and direct relaxation induced by baicalein in rat mesenteric artery. Eur J Pharmacol 374: 41-47, 1999.

13. Waisundara VY, Siu SY, Hsu A, Huang D and Tan BK: Baicalin upregulates the genetic expression of antioxidant enzymes in type-2 diabetic Goto-Kakizaki rats. Life Sci 88: 1016-1025, 2011

14. Chow JM, Shen SC, Wu CY and Chen YC: 12-o-Tetradecanoylphorbol 13-acetate prevents baicalein-induced apoptosis via activation of protein kinase $\mathrm{C}$ and JNKs in human leukemia cells. Apoptosis 11: 1999-2011, 2006.

15. Lee JH, Li YC, Ip SW, Hsu SC, Chang NW, Tang NY, Yu CS Chou ST, Lin SS, Lino CC, et al: The role of $\mathrm{Ca}^{2+}$ in baicalein-induced apoptosis in human breast MDA-MB-231 cancer cells through mitochondria-and caspase-3-dependent pathway. Anticancer Res 28: 1701-1711, 2008

16. Králíčková M and Vetvicka V: Endometriosis and ovarian cancer World J Clin Oncol 5: 800-805, 2014.

17. Liu H, Dong Y, Gao Y, Du Z, Wang Y, Cheng P, Chen A and Huang $\mathrm{H}$ : The fascinating effects of baicalein on cancer: A review. Int J Mol Sci 17: pii: E1681, 2016.

18. Ryan IP, Schriock ED and Taylor RN: Isolation, characterization, and comparison of human endometrial and endometriosis cells in vitro. J Clin Endocrinol Metab 78: 642-649, 1994.

19. Králíčková M, Losan $P$ and Vetvicka V: Endometriosis and cancer. Womens Health (Lond) 10: 591-597, 2014.

20. Brown J and Farquhar C: An overview of treatments for endometriosis: JAMA 313: 296-297, 2015.

21. Flower A, Liu JP, Lewith G, Little P and Li Q: Chinese herbal medicine for endometriosis. Cochrane Database Syst Rev 5: CD006568, 2012.

22. Dobos G and Tao I: The model of Western integrative medicine: The role of Chinese medicine. Chin J Integr Med 17: 11-20, 2011
23. Kong S, Zhang YH, Liu CF, Tsui I, Guo Y, Ai BB and Han FJ: The complementary and alternative medicine for endometriosis: A review of utilization and mechanism. Evid Based Complement Alternat Med 2014: 146383, 2014.

24. Jin Z, Wang L and Zhu Z: Effect of guixiong xiaoyi wan in treatment of endometriosis on rats. Evid Based Complement Alternat Med 2015: 208514, 2015.

25. Ye F, Wang H, Zhang L, Zou Y, Han H and Huang J: Baicalein induces human osteosarcoma cell line MG-63 apoptosis via ROS-induced BNIP3 expression. Tumour Biol 36: 4731-4740, 2015.

26. Liu TY, Gong W, Tan ZJ, Lu W, Wu XS, Weng H, Ding Q, Shu YJ, Bao RF, Cao Y, et al: Baicalein inhibits progression of gallbladder cancer cells by downregulating ZFX. PLoS One 10: e0114851, 2015.

27. Takahashi H, Chen MC, Pham H, Angst E, King JC, Park J, Brovman EY, Ishiguro H, Harris DM, Reber HA, et al: Baicalein, a component of Scutellaria baicalensis induces apoptosis by Mcl-1 down-regulation in human pancreatic cancer cells. Biochim Biophys Acta 1813: 1465-1474, 2011.

28. Kuo HM, Tsai HC, Lin YL, Yang JS, Huang AC, Yang MD, Hsu SC, Chung MC, Gibson Wood W and Chung JG: Mitochondrial-dependent caspase activation pathway is involved in baicalein-induced apoptosis in human hepatoma J5 cells. Int J Oncol 35: 717-724, 2009.

29. Zhang Y, Song L, Cai L, Wei R, Hu H and Jin W: Effects of baicalein on apoptosis, cell cycle arrest, migration and invasion of osteosarcoma cells. Food Chem Toxicol 53: 325-333, 2013

30. Wu S, Zhou F, Zhang Z and Xing D: Mitochondrial oxidative stress causes mitochondrial fragmentation via differential modulation of mitochondrial fission-fusion proteins. FEBS J 278: 941-954, 2011.

31. Takahashi H, Chen MC, Pham H, Angst E, King JC, Park J, Brovman EY, Ishiguro H, Harris DM, Reber HA, et al: Baicalein, a component of Scutellaria baicalensis, induces apoptosis by Mcl-1 down-regulation in human pancreatic cancer cells. Biochim Biophys Acta 1813: 1465-1474, 2011.

32. Li-Weber M: New therapeutic aspects of flavones: The anticancer properties of Scutellaria and its main active constituents Wogonin, Baicalein and Baicalin. Cancer Treat Rev 35: 57-68, 2009. 